\title{
Nomenclatural and taxonomic comments on some taxa of Chenopodiaceae of the Himalayas and Tibet/Xizang
}

\author{
Sergei L. MOSYAKIN ${ }^{1}$, Bohumil MANDÁK ${ }^{2,3}$ \\ ${ }^{1}$ M.G. Kholodny Institute of Botany, National Academy of Sciences of Ukraine \\ 2 Tereschenkivska Str., Kyiv 01601, Ukraine \\ s.mosyakin@hotmail.com \\ ${ }^{2}$ Faculty of Environmental Sciences, Czech University of Life Sciences Prague \\ 129 Kamýcká, Praha 6 - Suchdol 165 21, Czech Republic \\ mandak@fzp.czu.cz \\ ${ }^{3}$ Institute of Botany, Czech Academy of Sciences \\ 1 Zámek, Průhonice 252 43, Czech Republic \\ bohumil.mandak@ibot.cas.cz
}

Mosyakin S.L., Mandák B. 2020. Nomenclatural and taxonomic comments on some taxa of Chenopodiaceae of the Himalayas and Tibet/Xizang. Ukrainian Botanical Journal, 77(6): 413-427.

\begin{abstract}
Nomenclatural corrections and comments are provided on several taxa of Chenopodiaceae occurring in the Himalayas and Xizang/Tibet and adjacent areas, following the recent monographic revision of the family in that region and earlier publications. In particular, the original identity of the name Atriplex bengalensis (Chenopodium bengalense) is discussed and it is confirmed, based on additional evidence, that the name was originally (before its epitypification in 2014) applicable to a robust diploid of the Chenopodium ficifolium aggregate, not to the robust hexaploid currently known as $C$. giganteum. It is thus also concluded that the recent proposal by Mosyakin and Mandák (2018) to conserve the name C. giganteum with a conserved type corresponding to the current understanding and application of that name will best serve nomenclatural stability. A nomenclatural solution alternative to the proposal to reject the name A. bengalensis might be the following: (1) to conserve the name Atriplex bengalensis with a conserved type (in fact, to reject the current epitype that taxonomically differs from the lectotype) and (2) to conserve simultaneously the name C. ficifolium against $C$. bengalense. The nomenclaturally paradoxical situation with the names Chenopodium pallidum, $C$. harae, and Atriplex pallida (all now considered homotypic, as justified by Mosyakin and McNeill in 2018), which emerged from the conflicting lectotypification and epitypification of the name $C$. pallidum, is revisited and reconsidered. Possible options for dealing with that nomenclatural problem are outlined: (1) keeping the status quo, (2) proposing to conserve the name C. pallidum with a conserved type other than the standing lectotype, and (3) proposing to reject the name $C$. pallidum. The last option is considered preferable. Additional considerations are presented on a possible taxonomic identity of Chenopodium strictum as originally described by Roth; it is confirmed that that name was misapplied to a widespread Eurasian tetraploid species now properly known as $C$. betaceum. The identity of the name Bassia fiedleri is discussed; being a replacement name for Echinopsilon divaricatum, it is homotypic with Bassia divaricata (Kar. \& Kir.) Kuntze (nom. illeg., non F. Muell.) and is a taxonomic synonym of Grubovia dasiphylla (as correctly stated by Kadereit and Freitag in 2011), but not a synonym of Bassia scoparia. Several comments on type designations of selected taxa of Chenopodiaceae from the Sino-Himalayan region are provided as well; e.g., for Acroglochin persicarioides and associated names, Chenopodium karoi, and Salsola monoptera.
\end{abstract}

Keywords: Atriplex, Bassia, Chenopodium, Chenopodiaceae, Salsola, China, India, Nepal, nomenclature, taxonomy, typification 
Мосякін С.Л. ${ }^{1}$, Мандак Б. ${ }^{2,3}$ 2020. Номенклатурні і таксономічні коментарі щодо деяких представників Chenopodiaceae флори Гімалаїв та Тибету (Сіцзану). Украӥнський ботанічний журнал, 77(6): 413-427.

${ }^{1}$ Інститут ботаніки ім. М.Г. Холодного НАН України

вул. Терещенківська 2, Київ 01601, Україна

${ }^{2}$ Факультет наук про довкілля, Чеський сільськогосподарський університет

вул. Камицка 129, Прага 6 - Сухдол 165 21, Чеська Республіка

${ }^{3}$ Інститут ботаніки Чеської академії наук

Пругоніце 252 43, Чеська Республіка

Реферат. Наведено номенклатурні коментарі та уточнення щодо декількох таксонів родини Chenopodiaceae, які представлені у флорі Гімалаїв і Тибету (Сіцзану) та деяких прилеглих територій і які були нещодавно розглянуті у монографічному опрацюванні родини у цьому регіоні, а також у деяких інших публікаціях. Зокрема, розглянуто ймовірне оригінальне застосування назви Atriplex bengalensis (Chenopodium bengalense). На основі додаткових даних підтверджено, що ця назва (з моменту її публікації і аж до її епітипіфікації у 2014 р.) стосувалася велетенського диплоїда з групи Chenopodium ficifolium, але не гігантського гексаплоїда, здебільшого відомого дотепер як C. giganteum. Тому прийняття нещодавньої номенклатурної пропозиції (Mosyakin, Mandák, 2018) щодо консервації назви C. giganteum із законсервованим типом, який відповідає сучасному розумінню та застосуванню цієї назви, було б найкращим для збереження номенклатурної стабільності. Можливе й номенклатурне рішення, альтернативне до пропозиції відхилити назву A. bengalensis, a caме: (1) законсервувати назву $A$. bengalensis із законсервованим типом (по суті, відхилити нинішній епітип, який таксономічно відрізняється від лектотипу) i (2) одночасно законсервувати назву C. ficifolium проти C. bengalense. Переглянута і обговорена номенклатурно парадоксальна ситуація з назвами Chenopodium pallidum, C. harae та Atriplex pallida (які усі зараз мають розглядатися як гомотипні, як це обгрунтовано у статті Mosyakin, McNeill, 2018), що виникла внаслідок суперечливих лектотипіфікації та епітипіфікації назви C. pallidum. Окреслені можливі варіанти вирішення цієї номенклатурної проблеми, а саме: (1) підтримання status quo, або (2) пропозиція законсервувати назву C. pallidum із законсервованим типом іншим, ніж нинішній лектотип, або (3) пропозиція відхилити назву C. pallidum. Останній варіант визнано найкращим. Представлені додаткові міркування щодо ймовірної таксономічної приналежності Chenopodium strictum в оригінальному розумінні автора виду; підтверджено, що ця назва невірно застосовувалася до розповсюдженого євразійського тетраплоїдного виду, який зараз відомий як C. betaceum. Обговорена таксономічна приналежність назви Bassia fiedleri; оскільки це замінювальна назва для Echinopsilon divaricatum, вона є гомотипною з Bassia divaricata (Kar. \& Kir.) Kuntze (nom. illeg., non F.Muell.) i таксономічним (гетеротипним) синонімом назви Grubovia dasiphylla (як це і було вірно вказано раніше), але не є синонімом назви Bassia scoparia. Також представлено декілька коментарів і уточнень щодо типіфікації декількох назв таксонів Chenopodiaceae з Китайсько-Гімалайського регіону; наприклад Acroglochin persicarioides та таксономічно пов'язаних назв, а також Chenopodium karoi, Salsola monoptera.

Ключові слова: Atriplex, Bassia, Chenopodium, Chenopodiaceae, Salsola, Індія, Китай, Непал, номенклатура, систематика, типіфікація

\section{Introduction}

The recently published monograph of Chenopodiaceae in the Himalayas (Bhutan, Nepal, and northern India: Himachal Pradesh, Jammu and Kashmir, Sikkim, and Uttarakhand) and Tibet (Xizang, China) (Sukhorukov et al., 2019) is an important contribution to world knowledge of the family, both in that region and in other geographic areas. Nevertheless, now that this publication is available, we consider it necessary to provide here several comments and corrections as an amendment for that treatment, mainly concerning the nomenclature and type designations for several taxa of Chenopodiaceae, as treated in Sukhorukov et al. (2019) and in some earlier publications. Acronyms of herbaria are given below following Index Herbariorum (Thiers, 2008-onward).
Further comments on the identity of Lamarck's specimens of Atriplex bengalensis $\equiv$ Chenopodium bengalense

Sukhorukov (in Sukhorukov, Kushunina, 2014) proposed to apply the name Chenopodium bengalense (Lam.) Spielm. ex Steud. (三Atriplex bengalensis Lam.) to the hexaploid species commonly known before as C. giganteum D.Don (see further details in: Mosyakin, Mandák, 2018b). In our formal nomenclatural proposal (Mosyakin, Mandák, 2018a) to reject the name Atriplex bengalensis we have already commented that the two original specimens (syntypes) of $A$. bengalensis in the Lamarck Herbarium [P, barcodes P00381128 (Fig. 1A) and P00381127 (Fig. 1B), the specimen P00381128 was designated as the lectotype: Sukhorukov, Kushunina, 2014: 18] almost certainly represent a diploid taxon related 
to C. ficifolium Sm. s. str. or belonging to the C. ficifolium aggregate. The nomenclatural confusion that resulted from the conflicting simultaneous lectotypification and epitypification of the name $A$. bengalensis was also briefly discussed in our proposals (see also a similar case of Chenopodium pallidum Moq. and associated names: Mosyakin, McNeill, 2018, and further details below). In Sukhorukov et al. (2019) the name C. bengalense is still applied, without any expression of doubt, to the taxon commonly accepted before under the name C. giganteum. As we mentioned, plants of Indian origin morphologically similar to the lectotype and isotype of $A$. bengalensis were cultivated by Bohumil Mandák and his research team in the Experimental Garden of the Botanical Institute CAS in Průhonice near Prague (Mosyakin, Mandák, 2018a), and those plants were uniformly diploid $(2 n=2 x=18)$ with the genome size (2C DNA content $1.8 \mathrm{pg}$ ) similar to that of $C$. ficifolium s. str. (see Mandák et al., 2016).

An additional historical specimen of Chenopodium bengalense ( $\equiv$ Atriplex bengalensis) that definitely originated from plants cultivated in the Paris Botanical Garden (from where the two original specimens from the Lamarck Herbarium also originated) is available at the James Edward Smith Herbarium at LINN (LINNHS 1584.23, image available from http://linnean-online. org/49133/ and https://plants.jstor.org/stable/10.5555/ al.ap.specimen.linn-hs1584-23). It is annotated as "Atriplex benghalensis [sic!] L. [here "L." probably means Lamarck, not Linnaeus]", with an abbreviation on the label "h. R. P." that almost certainly indicates the Royal Botanical Garden of Paris ("Hortus Regius Parisiensis"). As we can judge from digital images, the LINN-HS specimen is conspecific with the two original specimens from the Lamarck Herbarium.

A careful review of earlier literature on Indian taxa of Chenopodium provided further compelling evidence supporting our conclusion on the true taxonomic identity of the two original specimens of $A$. bengalense from the Lamarck Herbarium at P.

Indian authors working in the field of genetics and cytogenetics of Chenopodium quite often recognized several "cytotypes" within groups of Indian plants identified as C. album sensu lato (see, e.g. Mehra, Malik, 1963; Partap, Kapoor, 1985a, b, 1987; Mukherjee, 1986; Bera, Mukherjee, 1987; Kumar, Subramaniam, 1987; Partap, Upadbya, 1987; Bera, 1991; Bera et al., 1993; Gangopadhyay et al., 2002; Bhargava et al., 2005, 2006, 2007; Emmerling-Skala, 2005; Rana et al., 2010; etc.). In fact, C. album s. str. is represented only by hexaploids
$(2 n=6 x=64)$, while diploids and tetraploids belong, in the strict sense, to other species; see Mandák et al. (2018) for a general scheme of polyploid evolution in Chenopodium s. str. Thus, the name C. album was (and still is) in fact misapplied to plants with $2 n=2 x=18$ (diploids) and $2 n=4 x=36$ (tetraploids).

It seems that the $C$. ficifolium group is morphologically very diverse in India and adjacent regions of southern Asia (see Aellen, 1961; Pandeya et al., 1998; Pandeya, Pandeya, 2003; Mosyakin, 2016, and references therein), but morphological, geographical and evolutionary patterns of that diversity still remain poorly understood. Judging from the cited publications, most of Indian diploids (or even almost all of them?) of Chenopodium s. str. either belong to $C$. ficifolium s.l. or are at least closely related to it. In most cases, however, it is difficult to figure out which morphotypes are considered in the cited Indian publications.

Fortunately, Mukherjee (1986) provided brief morphological descriptions of plants and rather diagnostic photographs of leaves of his "C. album diploid" and "C. album polyploid". His Fig. 1 (upper part of the plant) and Fig. 2a (cauline leaf) labeled as "C. album diploid" (Mukherjee, 1986: 755; here reproduced as Fig. 2) evidently represent the morphotype morphologically most closely matching the original specimens (lectotype and syntype) of $A$. bengalensis from the Lamarck Herbarium (Fig. 1A and 1B); that morphotype, in our opinion, is closely related to C. ficifolium s. str., or, alternatively (depending on a species concept applied), can be even placed in C. ficifolium sensu lato as one of its infraspecific entities.

Moreover, Indian authors (e.g., Gangopadhyay et al., 2002; Rana et al., 2010) recognize at least two morphotypes within "diploid C. album", i.e. narrow-leaved and broad-leaved ones. Both these morphologically closely approach $C$. ficifolium s. str., but clearly represent different species, or at least subspecies, in cultivation (B. Mandák, personal observation). They markedly resemble what Sukhorukov and Kushunina (2014) and Sukhorukov et al. (2019) accepted as C. bengalense, i.e. tall robust annuals having more or less trilobate leaf blades with a markedly elongated terminal lobe and shorter lateral lobes located closer to the leaf base. In addition, seeds with small crater-like microdepressions in these $C$. bengalense-like plants assign this species rather to the diploid $C$. ficifolium s.l. than to any hexaploid species.

Some Indian plants evidently related to $C$. ficifolium are exceptionally robust or even gigantic; for example, 

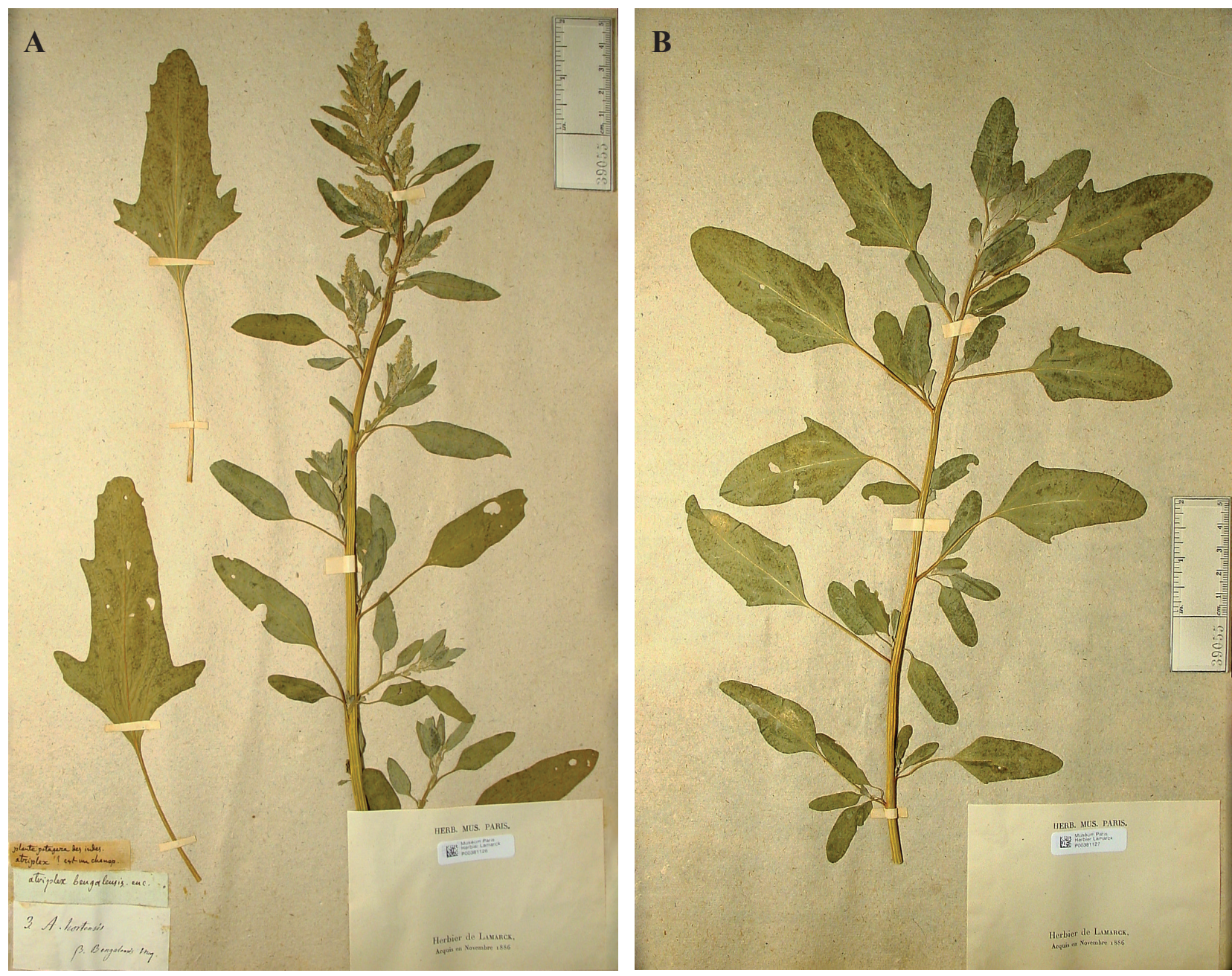

Fig. 1. The lectotype (P00381128, A) and syntype (P00381127, B) of Atriplex bengalensis Lam. = Chenopodium bengalense (Lam.) Spielm. ex Steud. (images from the Lamarck Herbarium, http://www.lamarck.cnrs.fr; accessed September 2018)

the plants initially provisionally labeled as belonging to the "CS population" (Singhal, 1994; see Fig. 3) that were later described as C. santoshii Pandeya, G.Singhal \& A.K.Bhatn. (Pandeya et al., 1998: 484; originally published as "santoshei", correctable under Art. 60.8, Note 4 of the ICN: Turland et al., 2018). According to Singhal (1994) and Pandeya et al. (1998), C. santoshii can grow up to $3.5 \mathrm{~m}$ tall. Probably those plants or other similar local robust diploids of India were progenitors of robust allohexaploid plants usually referred to as C. giganteum.

In addition to various cultivated hexaploids commonly identified as C. giganteum or C. album a.l., robust forms of the $C$. ficifolium species aggregate are also definitely cultivated in India as leaf vegetables locally and collectively known as bathua (Singh, 2015a, b; Singh et al., 2018). For example, the new leaf vegetable cultivar of "C. album" Kashi Bathua-2 recently developed at the ICAR - Indian Institute of Vegetable Research, Varanasi, Uttar Pradesh (Singh et al., 2018; additional plant images are available from https://www.researchgate. net/publication/332780339), in fact also belongs to the C. ficifolium group and by its morphological characters closely approaches the plants that Lamarck described as Atriplex bengalensis. The same is true for another recently established cultivar, Kashi Bathua-4; its digital images (habitus, leaves, fruits/seeds) kindly provided to the first author by Dr. B.K. Singh (ICAR - Indian Institute of Vegetable Research) leave no doubt that it is also related to $C$. ficifolium and at least very similar to (if not conspecific with) $C$. bengalense (as defined by its lectotype, not by its standing epitype).

Ukrainian Botanical Journal, 2020, 77(6) 

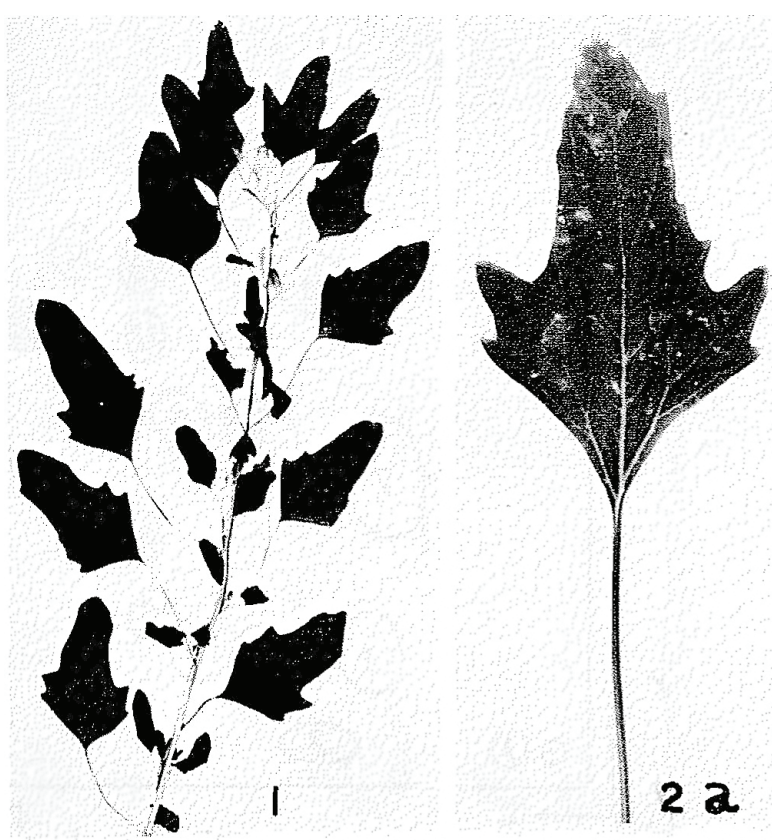

Fig. 2. "Chenopodium album diploid cytotype" sensu Mukherjee (1986: 755, Fig. 1, Fig. 2a); compare to Fig. 1.

A special taxonomic study of the underutilized crops (see Partap, Kapoor, 1987; Arora, 2014, etc.) and wild and weedy representatives of the Chenopodium album aggregate in the Indian subcontinent and other parts of southern and southeastern Asia is needed.

Thus, we think that, judging from morphological evidence, it is almost certain that Lamarck described under his name $A$. bengalensis the diploid plants belonging to the $C$. ficifolium aggregate (or to $C$. ficifolium s.1.); these plants were cultivated in Paris from seeds obtained from India. That conclusion provides further support to our proposals to reject the name $A$. bengalensis and to conserve the name $C$. giganteum with a conserved type to ensure the current application of the widely accepted names $C$. ficifolium and C. giganteum.

However, there might be an alternative nomenclatural solution. Now, when we have virtually no doubt that $C$. bengalense (according to its lectotype) represents a robust Indian taxon of the $C$. ficifolium group, it would be a pity to reject that name just because of its epitypification (Sukhorukov, Kushunina, 2014) with a morphologically poor specimen (MW0595516) almost certainly representing another species, and the resulting disruption of the nomenclature of $C$. giganteum. However, it would be also reasonable to safeguard the generally accepted and widely used name $C$. ficifolium against the earlier name $C$. bengalense. The latter will be the priority name at the species rank if these two taxa are considered as subspecies or some other infraspecific entities of one species. Thus, a two-step proposal would satisfy that need: (1) to conserve the name Atriplex bengalensis with a conserved type, thus allowing to get rid of the current epitype, and (2) to conserve simultaneously the name $C$. ficifolium against $C$. bengalense. Now we are considering that nomenclatural alternative. However, future amendments of the Code may change the nomenclatural situation (see below).

The problem of Chenopodium pallidum: additional comments and nomenclatural options

Probably the monograph of Himalayan and Tibetan Chenopodiaceae had been finalized before the article by Mosyakin and McNeill (2018) became available and therefore this nomenclatural note is not cited in Sukhorukov et al. (2019). However, the nomenclatural conclusions reached in our article are unchallengeable from the viewpoint of the current Shenzhen Code (ICN: Turland et al., 2018), even if they look somewhat paradoxical: Chenopodium pallidum Moq., by its epitypification (but not lectotypification!), is the correct name for a Himalayan species of Chenopodium, despite the fact that its lectotype in P belongs to Atriplex (!), while Chenopodium harae Sukhor. (originally published as "harai"; the orthographic error correctable under Art. 60.8 of the ICN) and Atriplex pallida (Moq.) Sukhor. are thus homotypic synonyms of C. pallidum. Despite that, the names Chenopodium harae and Atriplex pallida are listed as accepted in Sukhorukov et al. (2019), which is probably taxonomically logical but nomenclaturally incorrect.

Interesting enough, Sukhorukov et al. (2019: 44) cited the lectotype of the name $C$. pallidum that was designated in Sukhorukov and Kushunina (2014: 14) but did not cite the epitype that was designated in the same article on the same page. As we noted (Mosyakin, McNeill, 2018) and as follows from the relevant provisions of the ICN (Turland et al., 2018; see also Lendemer, 2020), it is the epitype, not a lectotype, that ultimately defines the application of a name.

In our opinion, there are three main options for dealing with the confusing nomenclatural situation created by conflicting lectotypification and epitypification of the name Chenopodium pallidum (Sukhorukov, Kushunina, 2014, 2015).

The first option is just to retain the status quo. In that case the names Chenopodium harae and Atriplex pallida will remain nomenclatural synonyms of Chenopodium 


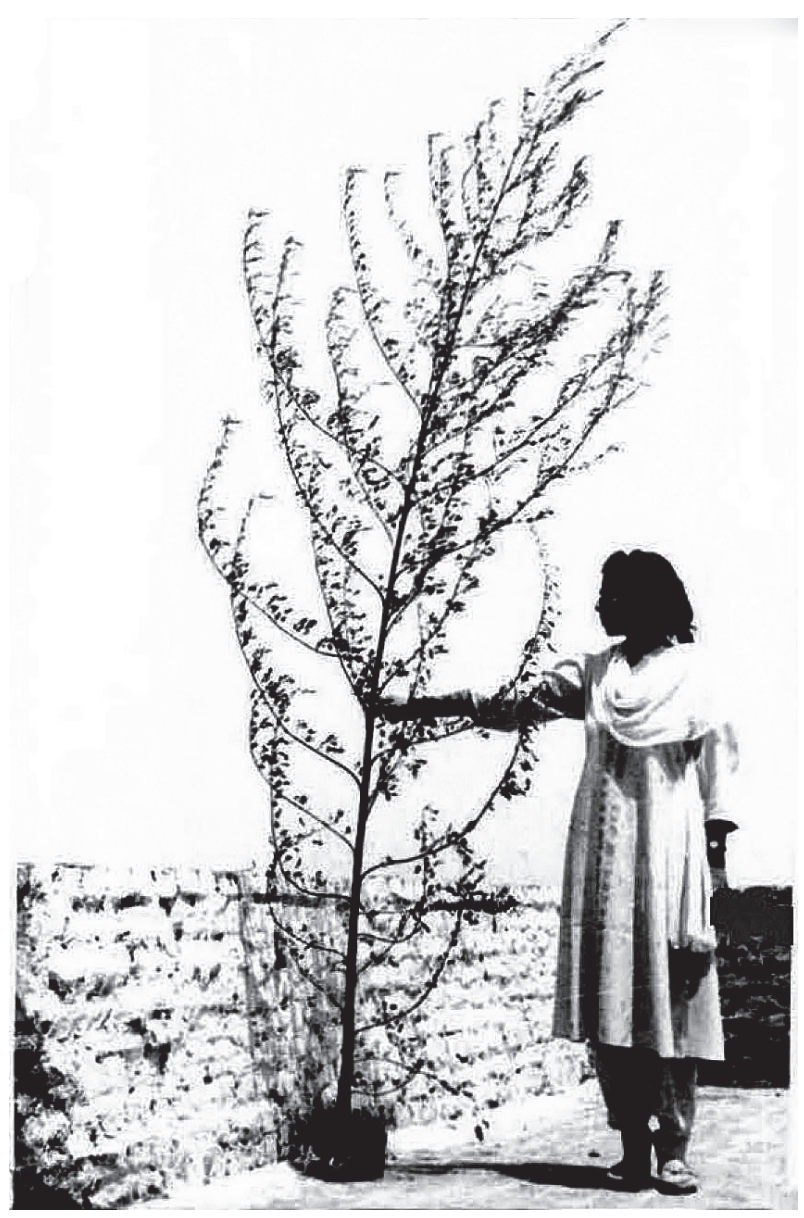

Fig. 3. "A mature plant of CS population" (Singhal, 1994, Plate 1.2G; reproduced from http://hdl.handle.net/10603/205080), a robust (up to $3.5 \mathrm{~m}$ tall) Indian taxon later described as Chenopodium santoshii (Pandeya et al., 1998); evidently related to diploid $C$. ficifolium s. str.

pallidum (according to its epitypification). No nomenclatural and taxonomic changes will be needed in that case; however, the genus-level identity conflict of the lectotype (an Atriplex) and the epitype (a Chenopodium) of the name $C$. pallidum will not be resolved.

On the other hand, if it is considered useful to restore the application of the name $C$. pallidum in accordance with the taxonomic identity of its lectotype (belonging to Atriplex), then the simplest way to do that would be to propose the name $C$. pallidum for conservation with a conserved type other than the standing lectotype (preferably another original specimen from the single gathering cited in the protologue). In that case, if that hypothetical conservation proposal is accepted, the current epitype of Chenopodium pallidum (belonging to Chenopodium) will have no standing because an epitype supports only the type to which it is linked by the typifying author (Art. 9.20, Note 8 of the ICN: Turland et al., 2018), the name Atriplex pallida will be the correct name for the species of Atriplex currently known as A. schugnanica Iljin (1936a: 123), and the name $C$. harae will become available for the species of Chenopodium now properly called C. pallidum due to its epitypification. However, in our opinion, the usefulness of such a conservation proposal is doubtful. It will submerge into synonymy the name Atriplex schugnanica that was and still is accepted in several publications and databases; e.g., Iljin (1936b: 97), Ikonnikov (1963: 99; 1979: 139), Grubov (1966: 32), Sidorenko (1968: 338), Pratov (1972: 50), Czerepanov (1995a: 181; 1995b: 347), Hedge, Jafri and Omer (in Freitag et al., 2001: 67), Sukhorukov (2006: 384), Zhu (in Zhu, Sanderson, 2017: 166, as Obione schugnanica (Iljin) G.L.Chu), POWO (2020-onward: http://www.plantsoftheworldonline.org/ taxon/urn:lsid:ipni.org:names:164138-1), etc.

The third option would be to propose the name Chenopodium pallidum for rejection. Anyway, that name remained forgotten for a long time and was taxonomically restored (in conflict with the generic identity of its original specimens) only in 2014 (Sukhorukov, Kushunina, 2014). If that rejection proposal is accepted, the name Atriplex schugnanica will be preserved for a species of Atriplex, the name Chenopodium harae will become available for a species of Chenopodium, and the generic identity conflict (the Atriplex lectotype versus the Chenopodium epitype) will be successfully resolved by nomenclatural rejection of the problematic name itself. At present we consider this nomenclatural option as preferable, and the relevant nomenclatural proposal has been prepared (Mosyakin, Mandák, submitted to Taxon, expected in 2021).

It should be noted that possible future changes in the International Code of Nomenclature... may open other options for cases such as epitypifications of Chenopodium pallidum and Atriplex bengalensis ( $\equiv$ Chenopodium bengalense, see above). For example, the recent proposal to amend the Code (Mazumdar et al., 2020: 631) advocated the following amended wording of the first sentence of Art. 9.20 (proposed amended text in bold): "The author who first designates (Art. 7.10, 7.11, and F.5.4) an epitype must be followed, but that choice is superseded if it is in serious conflict with the protologue, in which case an element that is not in conflict with the protologue is to be chosen". If that (or similarly worded) proposal is accepted, rejection or supersession of an erroneously designated epitype will become possible, and it will be much easier than the current procedure involving nomenclatural conservation or rejection. 
On a possible taxonomic identity of Chenopodium strictum as originally described by Roth: additional considerations

Sukhorukov et al. (2019: 32-33) commented on Chenopodium strictum Roth as follows: "Sukhorukov (2014) discovered that the plants growing in North Himalaya and in Europe differ in their morphological characters and $C$. betaceum Andrz. may be the correct name for the European plants. Furthermore, C. strictum material from Himalaya, from where the species was described, is scarce (Jammu and Kashmir, India). Further investigations are needed to discover which plants belong under this name". We agree that further investigations are needed and for those investigations to be productive and free from misunderstanding, some comments are needed as well.

From the wording cited above a reader may assume (even if that was not an original intention of the authors) that the taxonomic acceptance of the name $C$. betaceum for European tetraploids (they were also known before as C. striatum (Krašan) Murr, or under the misapplied name C. strictum auct. non Roth) was restored by Sukhorukov (2014). However, that is not the case.

In fact, Modest M. Iljin in his treatment of Chenopodiaceae in the fourth volume of the Flora of the Ukrainian SSR (Iljin, 1952: 306-308) explicitly restored the usage of the name $C$. betaceum for the species treated in the Flora of the USSR (Iljin, Aellen, $1936)$ as $C$. strictum. In the same volume, Iljin (1952) also taxonomically and nomenclaturally restored another species described by Antoni L. Andrzejowski (1862), C. acerifolium Andrz., and demonstrated that that name is of priority for the mainly East European or/and Euro-Siberian species earlier known as C. klinggraeffii Aellen, which was, in turn, the replacement name for the illegitimate combination C. hastatum (C. Klinggr.) Murr, non Phil. (see Uotila, Lomonosova, 2016; Mosyakin, 2017).

But even before Iljin (1952), Vladimir G. Chrshanovski [also transliterated as Khrzhanovskiy, Хржановський in Ukrainian, Хржановский in Russian; see a biographic note by Rubtsova (2004)] accepted the names $C$. acerifolium and $C$. betaceum in his treatment of Chenopodiaceae in the identification manual of vascular plants of Ukraine (Chrshanovski, 1950: 666); however, he provided no explanation for his taxonomic and nomenclatural decisions. Thus, Iljin (1952) was effectively the first author who not only returned from oblivion, but explicitly accepted the names $C$. acerifolium and $C$. betaceum, and also properly justified his Украӥнський ботанічний журнал, 2020, 77(6) restoration of these names for the two now generally recognized species occurring in East Europe and beyond. Already in their treatment of Chenopodium in the Flora of the USSR, Iljin and Aellen (1936: 35) commented that Indian plants are morphologically somewhat different from the European ones, and because of that they coined the combination C. strictum subsp. striatum (Krašan) Aellen \& Iljin. A comment suggesting that $C$. betaceum is probably the correct name for the European species was also made by Mosyakin (1996: 41-42), and later also by Sukhorukov (2014: 229). Further details and quotations (with translations) from Iljin (1952) and other sources were provided in Mosyakin (2017: 145-146; not cited in Sukhorukov et al., 2019).

However, until recently there was an obstacle to proper restoration of the name $C$. betaceum: no original Andrzejowski's specimens of that species were located in the 1990s - mid-2010s in the KW herbarium (where most of specimens of that researcher are deposited, mainly in the Besser historical collection - KW-BESS). It was documented that at least one original specimen of C. betaceum was on loan in BRNU (see Dvořák, 1992: 68 , footnote) but, if returned to $\mathrm{KW}$, it was probably misplaced and is still not yet located. In 2016 Pertti Uotila (H herbarium) kindly informed Sergei Mosyakin (KW) about the long-forgotten loan of two original specimens of $C$. acerifolium and one original specimen of $C$. betaceum. Upon the return of these specimens from $\mathrm{H}$ to $\mathrm{KW}$ the real identity of $C$. betaceum has now been confirmed beyond any reasonable doubt (Mosyakin, 2017). That author then designated as lectotype the specimen KW001002779 and explicitly accepted $C$. betaceum for the European and partly Asian tetraploid species to which the name $C$. strictum had been commonly misapplied in the $20^{\text {th }}$ century, following the problematic nomenclatural resurrection of $C$. strictum by Aellen (1929).

The geographic origin of the type of C. strictum was indicated very broadly in the protologue (Roth in Schultes, 1820: 264) and in the book by Roth (1821: 180), as "in India orientali", meaning in that case not the eastern part of India proper, but "East India" as opposed to the West Indies in the Western Hemisphere (see Mosyakin, 2017: 146). Despite this, Sukhorukov et al. (2019: 33) assumed that $C$. strictum was described "from Himalaya". In fact, Benjamin Heyne, who was the collector of the original specimen(s) of $C$. strictum, never visited the Himalayan region but did most of his collecting in the southern part of India, within the territories of the present-day states of Tamil Nadu, Karnataka, and Andhra Pradesh [Heyne 
(1814), Burkill (1953), Stewart (1982); for a summary, see Mosyakin (2017: 146) and references therein].

Heyne (1814: 54, 133) mentioned a species of Chenopodium (as "Chenopodium viride", most probably meaning a Chenopodium with lax inflorescences) twice in his book, of which the only original mention (not translated from an Indian source) was on page 54 in Table V entitled the List of Vegetables, the Leaves of which are used by the Natives in their Curries or Stews. This part of his book is included in "Tract II. Statistical fragments of the Mysore", in which Heyne described his observations during the Mysore Survey, for which he was appointed in 1800 as a surgeon and assistant to Colonel Colin Mackenzie, the superintendant of that survey who led it from 1799 until 1810 (Edney, 1997: 175-176). Mysore (now Mysuru, Karnataka) in the early $19^{\text {th }}$ century was the center of the princely state of Mysore in Southern India. Heyne also participated in a general agricultural survey of the Mysore and Malabar territories (Roy, 1986: 26), and his other scientific activities were also confined to Southern India (see Bor, 1954; Stewart, 1982; Desmond, 1992; Watson, Noltie, 2016; etc.).

Consequently, the original material of C. strictum was most probably collected somewhere in the southern part of India. Thus, the claim that "the plants growing in North Himalaya and in Europe differ in their morphological characters" (Sukhorukov et al., 2019: 3233 ) is probably valuable from a biogeographic viewpoint because it improves our knowledge of the actual range of the Eurasian plants now properly called C. betaceum; however, it tells us nothing about possible differences between the type of C. strictum (most probably a southern Indian plant) and the European plants to which the latter name was misapplied.

It is usually assumed that the original specimen or specimens of C. strictum has/have been destroyed during World War II with many other historical collections in Berlin-Dahlem (B) (see e.g., Merrill, 1943; Sleumer, 1949; Pilger, 1953; Hiepko, 1987) and only one fragment of an original specimen is still extant in the Paul Aellen herbarium at $\mathrm{G}$ (for further details and additional relevant references, see Mosyakin, 2017). That fragment in G is the standing lectotype of $C$. strictum designated by Dvořák (1989: 198, 201, Fig. 3).

But is it possible that some other specimen or specimens of the original collection(s) of Heyne still exists/exist?

During the preparation of our nomenclatural proposal to conserve C. giganteum (Mosyakin, Mandák, 2018) the first author studied the digital images of Chenopodium specimens now deposited in the Wallich herbarium at $\mathrm{K}$. It is known that this important collection (see Anonymous, 1913; Candolle, Radcliffe-Smith, 1981; Stafleu, Cowan, 1988; Prakash, 2016; etc.) contains numerous specimens collected in India by Heyne; these specimens were transferred to the Wallich collection as part of the so-called "Madras herbarium" (Anonymous, 1913; Watson, 2013a-onward, 2013b-onward). As explained by Watson (2013b-onward), "In 1829 the East India Company permitted Wallich to add several other collections of dried plants, also kept in the India museum, into his distribution scheme, 'principally with a view to the distribution of their duplicates.' On page 61, Wallich details these additional collections (herbaria), and recounts how they will be indicated in his listing". In particular, it was noted that 'Herb. Madras' "is the large herbarium, with many duplicates, formed by Tranquebar Missionaries Johan Godfried (or Gottfried) Klein (17661821), Benjamin Heyne (1770-1819) \& Johan Peter Röttler (1749-1836). There are also entries under their separate names, e.g. 'Herb. Heyn.', etc.". Heyne not only left some of his specimens in London during his leave in 1813-1816 but also in 1816, before returning to India, gave most of his collection to A.W. Roth (Anonymous, 1913; Bor, 1954, etc.).

It is noteworthy that plant fragments on at least one sheet from the Wallich herbarium closely match the extant type fragment from $\mathrm{G}$, and the two specimens mounted on that sheet are marked one as originated from Heyne (Wallich Catalogue No. 6952.[E], K barcode K001126338, http:// specimens.kew.org/herbarium/K001126338) and another as part of the "Madras herbarium" (Wallich Catalogue No. 6952.[A], K barcode K001126337, http://specimens. kew.org/herbarium/K001126337) (Wallich, 1832: page 233, entry 6952).

It is possible thus that the two morphotypes mounted on the sheet K001126337/K001126338 may represent Heyne's duplicates of the specimens used by Roth that were deposited in $\mathrm{B}$, or at least were associated with these collections, representing the same or closely related species because they originated from the same collector and most probably from the same region/source. In our opinion, the plant fragment mounted in the left-side bottom corner of the sheet and tentatively associated with the Madras Herbarium and Wallich Catalogue No. 6952.[E] is most similar to the type fragment in $\mathrm{G}$, having a very similar lax partial inflorescences and almost lanceolate upper leaves. The specimen associated with Heyne and Wallich Catalogue No. 6952.[A] is probably represented by two branches and a separate leaf 
mounted at the right-side of the sheet. That specimen also shows some similarity to the G lectotype of C. strictum, especially if lanceolate upper leaves are considered; however, inflorescences in that specimen seem to be more condensed that in the $G$ lectotype. Also, the letter E written in pencil near the separate leaf is followed by a question mark, so the actual association of the plant fragments mounted on that sheet may be questionable. In any case, judging from morphological characters observable on scanned digital images, both plants belong to the $C$. album aggregate, they were probably hexaploids, and both are not the same as the European specimens of $C$. betaceum.

Of course, at present it is impossible to prove beyond doubt that any of the discussed specimens from the Wallich herbarium at $\mathrm{K}$ is indeed associated with one or both names in Chenopodium coined by Roth (in Schultes, 1820; also Roth, 1821). However, we may accept the similarity of these plant fragments at $\mathrm{K}$ with the standing lectotype at $G$ as circumstantial evidence in favor of the current interpretation of C. strictum as some yet obscure morphotype (hexaploid?) of the C. album aggregate but not as the priority name for any of Eurasian tetraploids. Thus, one rather widespread species of that tetraploid complex (also represented by $C$. striatiforme Murr, C. novopokrovskyanum (Aellen) Uotila, and some other "narrow" species) should be now properly accepted as $C$. betaceum $(=C$. striatum), as it was, first after Andrzejowski (1862), accepted by Chrshanovski (1950) and then confirmed and convincingly justified by Iljin (1952).

\section{The nomenclatural identity of the name Bassia fiedleri}

Sukhorukov et al. (2019: 106) listed the name Bassia fiedleri Aellen (1961: 713) as a new synonym ("syn. nov.") of the accepted name Bassia scoparia (L.) A.J.Scott (三Kochia scoparia (L.) Schrad.) and provided the following comment: "Aellen (in Hegi 1961) stated a new name instead of Bassia divaricata (Kar. \& Kir.) Kuntze (1891) [now Grubovia dasyphylla (Fisch. \& C.A.Mey.) Freitag \& Kadereit], non Bassia divaricata F. Muell. (1882). The name Bassia fiedleri was accepted as a synonym of Grubovia dasyphylla (Kadereit, Freitag, 2011). However, the analysis of the material in $G$ collected by O. Fiedler in Germany (as an alien plant) and treated by P. Aellen clearly shows that Bassia fiedleri is conspecific with Bassia scoparia".

The same conclusion is also stated in the Abstract (Sukhorukov et al., 2019: 1): "Bassia fiedleri, previously considered as conspecific with Grubovia dasyphylla, is added to the synonymy of Bassia scoparia".
However, these statements are incorrect. It is evident (and is correctly mentioned by Sukhorukov et al., 2019) that Aellen coined Bassia fiedleri as a replacement name for Echinopsilon divaricatum Kar. \& Kir. Aellen thought that it was necessary to transfer the species name E. divaricatum to Bassia. However, it was impossible to use for that species-rank taxon the epithet "divaricata" because of the existence of the earlier name Bassia divaricata (R.Br.) F.Muell. (Mueller, 1882: 30) [三 Anisacantha divaricata R.Brown (1810: 410)] referable to an Australian species now accepted as Sclerolaena divaricata (R.Br.) Sm. (see Scott, 1978: 112, Wilson, 1984: 259, etc.), which pre-dates the combination Bassia divaricata made by Kuntze (1891: 546) for the Asian species. In his treatment Aellen (1961: 713) clearly stated that his name is "nom. nov." and further specified in the footnote: "Echinopsilon divaricatum muß als Bassia wegen der älteren Bassia divaricata F. v. Muell., Cens. Austr. Pl. 30 (1882) - einen anderen Namen erhalten" ["Echinopsilon divaricatum as Bassia got another name - because of the earlier [name] Bassia divaricata F. v. Muell., Cens. Austr. P1. 30 (1882)"].

According to Art. 7.4 of the ICN (Turland et al., 2018), a replacement name (in our case, Bassia fiedleri) is typified by the type of its replaced name (here, Echinopsilon divaricatum), even though it may have been applied erroneously to a taxon now considered not to include that type.

Indeed, Aellen (1961: 714) also indicated that plants of his Bassia fiedleri were collected in Central Europe only once, in 1955 by O. Fiedler, as an alien species introduced with imported wool in Leipzig: "Im Gebiet nur einmal mit Wolle eingeschleppt bei der Leipziger Wollkämmerei an einer Schutthalde zahlreich aufgetreten (1955, O. Fiedler)". However, even if these alien plants collected in Germany were misidentified and actually represented B. scoparia, as revealed by Sukhorukov et al. (2019), that fact does not give any reason for synonymization of Aellen's replacement name with the latter species.

Consequently, Bassia fiedleri (as well as its replacement name Echinopsilon divaricatum) is the name homotypic with Bassia divaricata (Kar. \& Kir.) Kuntze (nom. illeg., non F. Muell. 1982) and a taxonomic synonym of Grubovia dasyphylla (Fisch. \& C.A.Mey.) Freitag \& Kadereit, as it was correctly stated by Kadereit and Freitag (2011). If deemed necessary, "Bassia fiedleri auct. non Aellen" can be mentioned under B. scoparia, but only as a misapplied name, not as a true synonym. 


\section{Comments on typification statements}

\section{Acroglochin persicarioides (Poir.) Moq.}

The type of the name Amaranthus persicarioides Poir. (the basionym of Acroglochin persicarioides (Poir.) Moq.) was cited by Sukhorukov et al. (2019: 84) as "not designated, P?". That name and other names associated with Acroglochin were discussed by Iamonico (2018), who provided typification information (including newly made lecto- and neotypifications) for all names concerned. However, the article by Iamonico (2018) was published on 14 December 2018, while the article by Sukhorukov et al. (2019) is dated by 31 January 2019. Naturally, it was probably too late to include the article by Iamonico in the list of references in Sukhorukov et al. (2019).

In particular, Iamonico (2018: 199) lectotypified Acroglochin chenopodioides Schrad. (cited by Sukhorukov et al. (2019) as "existence [of the type] not certain") on the specimen LE00018195 from Schrader's herbarium and neotypified the name Amaranthus persicarioides on the same specimen, thus making these two names homotypic by their lecto- and neotypification.

For the name Amaranthus diandrus Spreng., Sukhorukov et al. (2019: 84) reported its type as "Lectotype (Sukhorukov, designated here): NEPAL, Sep 1791, Spreng.[el] (L1677349!)". Iamonico (2018: 199) earlier designated a neotype for that name. A neotype serves as a nomenclatural type only if no original material is extant or as long as it is missing (Art. 9.8 of the ICN: Turland et al. 2018). According to Art. 9.19(a) of the ICN, the choice of a neotype is superseded if any of the original material is found to exist. Thus, the lectotypification made by Sukhorukov, if it is based on an element representing extant original material, supersedes the neotype designation by Iamonico (2018).

\section{Chenopodium karoi (Murr) Aellen}

The lectotype of the basionym of that species name, C. album subsp. karoi Murr (1923: 97), was reported as "Lectotype (designated here by Sukhorukov): [RUSSIA] Nerczynsk [Nerchinsk], dump places, 1892, Karo 169 (G00405813!)" (Sukhorukov et al., 2019: 24). Earlier Uotila and Lomonosova (2016: 226) cited that specimen as the holotype. They admitted that there was no citation of any particular specimen in the protologue (Murr, 1923: 97) but anyway concluded that "Clearly this [i.e. G00405813 - S.M.] is the only sheet that was in Murr's possession and it was used for describing the new subspecies". However, in the context of the current
Shenzhen Code (Turland et al., 2018) and the earlier versions of the Code (see further details, comments and recommendations in McNeill, 2014; also Turland et al., 2020) the holotype status of that specimen is not evident. Because of that the formal lectotype designation by Sukhorukov et al. (2019) is justified; nevertheless the reference to the type statement by Uotila and Lomonosova (2016) was desirable.

A proposal to amend the Code (Art. 9.10) should be probably considered for cases of original elements erroneously indicated on or after 1 January 2001 as holotypes to be corrected to lectotypes, in addition to the proposal by Turland et al. (2020).

Halogeton glomeratus (M.Bieb.) C.A. Mey. (三Anabasis glomerata M.Bieb.)

Sukhorukov et al. (2019: 126) reported the type of Anabasis glomerata as "Lectotype (designated here by Sukhorukov): Ex Sibiria [From Siberia], Salesow [Zalesov] (LE!)". However, Grubov (1966: 116) provided exactly the same type information: "Описан из «Сибири», тип в Ленинграде" ("Described from «Siberia», type in Leningrad") and further commented that the species was described as based on collections of Zalesov "from Siberia", with no exact location and date given. Grubov also provided brief historical information about travels of Zalesov and suggested that the type specimen in LE originated either from the Lake Zaisan area (eastern Kazakhstan) or from the Chuya Steppe (Altai Republic, Russia). As we see, no new information on the type was provided in Sukhorukov et al. (2019) as compared to the type statement of Grubov (1966; see also Hedge et al. in Freitag et al., 2001: 202), and thus the effective type designation, correctable to lectotype under Art. 9.10 of the ICN (Turland et al., 2018), in that case should be credited to Grubov.

\section{Salsola monoptera Bunge}

While discussing Salsola monoptera, Sukhorukov et al. (2019: 125) provided the following type statement: "Lectotype (Sukhorukov, designated here): Mongolia chinensis in itineris ad Chinam, [year] 1840 [Tatarinow s.n.] (LE!)". The explanation for the lectotype designation was provided in a note (Sukhorukov et al., 2019: 125): "Note. Bunge (1879) did not state a herbarium for the type specimen. Rilke (1999) and Grubov (2000) indicated that the holotype is in LE, but the Bunge herbarium is also deposited in some other herbaria, especially in $G$ and $\mathrm{P}$. Choosing a lectotype, we follow the suggestion of McNeill (2014) since no collection number and herbarium are indicated in the protologue". 
The statement is based on the misunderstanding or misinterpretation of the recommendations provided by McNeill (2014). In fact, Art. 9.10 of the ICN (Turland et al., 2018) is directly applicable in this case: "The use of a term defined in the Code (Art. 9.1, 9.3 and 9.5-9.9) as denoting a type, in a sense other than that in which it is so defined, is treated as an error to be corrected...". Already in 1936, Iljin (1936b: 216) indicated that the type of S. monoptera is in LE ("Тип в Ленинграде") and Grubov (1966: 83) confirmed that and provided more details relevant to the type (in Russian: "Описан из Монголии (на пути между городами Калганом и УланБатором), тип в Ленинграде", meaning "Described from Mongolia (on the way between Kalgan and UlanBator [Ulaanbaatar] towns), the type is in Leningrad"), but without citing the actual specimen more precisely. Rilke (1999), in turn, referred to these two publications, but also cited the LE specimen (as "holotype"). Thus, the lectotypification of the name S. monoptera proposed by Sukhorukov (in Sukhorukov et al., 2019: 125) was unnecessary because the "holotype" (or the holotype) from LE indicated by Rilke (1999: 103) and later by Novoselova (2000: 91) in Grubov (2000) (but not directly by Grubov, 2000) is correctable to the lectotype, and that lectotypification should be thus credited to Rilke.

Even if there are two or more original specimens available in LE, Rilke's statement in her monograph of 1999 should be accepted as the first-step lectotypification; however, currently there is no information on the existence of any additional original specimens in LE. Since that type indication/designation has been made by Rilke before 1 January 2001 (Art. 7.11 of the ICN), the phrase "designated here" (hic designatus) or an equivalent was not necessary.

\section{Concluding remarks}

An earlier version of this article (which was, however, quite close to the present version) was submitted in August 2020 to a journal but was promptly (in just five days after the submission date) rejected following a recommendation in an open review by one of the authors whose opinions and some taxonomic and/or nomenclatural decisions are discussed or corrected here. We assume that such reviewing practice is not the best model to be followed, but anyway, we respect and accept the editorial decision. We emphasize that our intention was to provide to the users of botanical information the nomenclaturally correct solutions for selected taxa in strict accordance with the current rules of nomenclature (Shenzhen Code, Turland et al., 2018) and to express, freely and openly, our opinions on several taxonomically problematic cases. The reviewer complained that some nomenclatural opinions on several taxa have been already expressed, at least in part, in earlier publications by Mosyakin and coauthors (e.g., Mosyakin, 2017; Mosyakin, McNeill, 2018; Mosyakin, Mandák, 2018a, b). In fact, here we provide additional (both direct and indirect) evidence for several noteworthy cases, as compared to arguments presented in our earlier articles, but since our earlier arguments were ignored (at least partly) or probably went unnoticed, we considered it useful to emphasize and further strengthen those arguments here. Nothing personal, just science.

\section{Acknowledgements}

The authors are grateful to the reviewers for their useful comments and suggestions, in particular, to Peter J. de Lange (Environment and Animal Sciences, Unitec Institute of Technology, Auckland, New Zealand) for his editorial recommendations. We are grateful to Binod Kumar Singh (ICAR-Indian Institute of Vegetable Research, Varanasi, Uttar Pradesh, India) for providing additional photographs of plants belonging to two Kashi Bathua cultivars from India. Ganna V. Boiko and Vera P. Hayova (M.G. Kholodny Institute of Botany, National Academy of Sciences of Ukraine, Kyiv, Ukraine) skilfully guided the present submission through the editorial process and made several improvements to the text and images. The taxonomic and nomenclatural work of Sergei Mosyakin was in part supported by the National Academy of Sciences of Ukraine (project 0117U004024) and research of Bohumil Mandák was supported by the Ministry of Education, Youth and Sports of the Czech Republic (LTAUSA18004), the Czech Science Foundation (20-20286S), and is part of the long-term research development project RVO 67985939.

\section{References}

Aellen P. 1929. Chenopodium strictum Roth (1821), ein älterer Name für Chenopodium striatum (Kraš.) Murr (1896). Magyar Botanikai Lapok, 26: 105-107.

Aellen P. 1960-1961. Chenopodiaceae. In: Hegi G. Illustrierte Flora von Mitteleuropa, $2^{\text {nd }}$ ed., vol. 3, part 2, Lief. 2-4. München: Lehmann Verlag [Reprinted: Berlin \& Hamburg: Paul Parey Verlag, 1979], pp. 533-762.

Andrzejowski A. 1862. Continuatio Enumerationis Plantarum sponte in Gubernio Podolico et locis adjacentibus crescentium. Universitetskie Izvestiya (Kiev), [volume 
of 1862], 7: 94-142. [Alternative Russian title: Андржиевский А. 1862. Продолжение исчисления растений Подольской губернии и смежных с нею мест. Университетские известия (Киев), [т. 1862 г.] 7: 94-142].

Anonymous. 1913. The Wallichian Herbarium. Bulletin of Miscellaneous Information (Royal Botanic Gardens, Kew), [vol. of 1913], 7: 255-263. Available at: http://www. jstor.org/stable/4115049; https://doi.org/10.2307/4115049

Arora R.K. 2014. Diversity in underutilized plant species An Asia Pacific perspective. New Delhi, India: Bioversity International, 203 pp. Available at: https:/www. bioversityinternational.org/fileadmin/user_upload/online library/publications/pdfs/Diversity_in_Underutilized_Plant_Species_An_Asia-Pacific_Prespective_1938.pdf

Bera B. 1991. Cytomorphological and biochemical investigations on three cytotypes of Chenopodium album L.: PhD Thesis. Calcutta [Kolkata]: University of Calcutta (Department of Botany), vii +192 pp. Available at: http://hdl.handle.net/10603/161830

Bera B., Mukherjee K.K. 1987. Phenotypic variability in Chenopodium album. The Nucleus, 30: 50-53.

Bera B., Das S., Mukherjee K.K. 1993. Morphological studies on three cytotypes of Chenopodium album L. of lower Gangetic plains, West Bengal, India. Phytomorphology, 43: 93-103.

Bhargava A., Rana T.S., Shukla S., Ohri D. 2005. Seed protein electrophoresis of some cultivated and wild species of Chenopodium. Biologia Plantarum, 49(4): 505-511. https://doi.org/10.1007/s10535-005-0042-5

Bhargava A., Shukla S., Ohri D. 2006. Karyotypic studies on some cultivated and wild species of Chenopodium (Chenopodiaceae). Genetic Resources and Crop Evolution, 53: 1309-1320. https://doi.org/10.1007/ s10722-005-3879-8

Bhargava A., Shukla S., Ohri D. 2007. Genome size variation in some cultivated and wild species of Chenopodium (Chenopodiaceae). Caryologia 60(3): 245-250. https:// doi.org/10.1080/00087114.2007.10797943

Bor N.L. 1954. Notes on Asiatic grasses: XX. Indian grasses in Roth's Herbarium. Kew Bulletin, 9(4): 545-548. https:// doi.org/10.2307/4114547

Brown R. 1810. Prodromus florae Novae Hollandiae et Insulae Van-Diemen. Londini [London]: Typis Richardi Taylor et socii, viii + pp. 145-590. https://doi.org/10.5962/ bhl.title. 52309

Burkill I.H. 1953. Chapters on the history of botany in India. 1. From the beginning to the middle of Wallich's service. Journal of the Bombay Natural History Society, 51(4): 846-878.

Candolle R. de, Radcliffe-Smith A. 1981. Nathaniel Wallich, MD, PhD, FRS, FLS, FRGS, (1786-1854) and the Herbarium of the Honourable East India Company, and their relation to the de Candolles of Geneva and the Great Prodromus. Botanical Journal of the Linnean Society, 83(4): 325-348. https://doi.org/10.1111/j.1095-8339.1981. tb00355.x
Chrshanovski V.G. 1950. Chenopodiaceae. In: Klokov M.V. (Ed.). Identification manual of plants of the Ukr. SSR. Kyiv: State Publisher of Agricultural Literature of the Ukr. SSR, pp. 662-680. [Хржановський В.Г. 1950. Chenopodiaceae. В кн.: Визначник рослин УРСР. Ред. М.В. Клоков. Київ: Державне видавництво сільськогосподарської літератури УРСР, с. 662-680].

Czerepanov S.K. 1995a. Vascular plants of Russia and adjacent states (the former USSR). Cambridge; New York: Cambridge University Press, $\mathrm{x}+516 \mathrm{pp}$.

Czerepanov S.K. 1995b. Plantae Vasculares Rossicae et civitatum collimitanearum (in limicis URSS olim). St. Petersburg: Mir i Semya-95, 992 pp. [Черепанов C.K. 1995b. Сосудистые растения России и сопредельных государств (в пределах бывшего СССР). СанктПетербург: Мир и семья-95, 992 с.].

Desmond R. 1992. The European discovery of the Indian flora. Oxford: Oxford University Press \& Royal Botanic Gardens, Kew, viii + 355 pp.

Dvořák F. 1989. Study on Chenopodium strictum agg. Feddes Repertorium, 100(5-6): 197-234.

Dvořák F. 1992. Study of Chenopodium subopulifolium J. Murr emend D. Feddes Repertorium, 103(1-2): 49-69. https:// doi.org/10.1002/fedr.19921030109

Dvořák F. 1993. Relationships and diagnostic characters of Chenopodium striatiforme J. Murr, C. striatum (Krašan) J. Murr and C. strictum Roth. Feddes Repertorium, 104(78): 439-449. https://doi.org/10.1002/fedr.19931040704

Edney M.H. 1997. Mapping an Empire: the geographical construction of British India, 1765-1843. [Vol. 10 of the Mapping an Empire series]. Chicago \& London: The University of Chicago Press, $458 \mathrm{pp}$.

Emmerling-Skala A. 2005. "Sultan der Gemüsegärten"? der Weiße Gänsefuß (Chenopodium album L.) als Nahrungspflanze. Schriften des Vereins zur Erhaltung der Nutzpflanzenvielfalt, 3: 1-143.

Freitag H., Hedge I.C., Jafri S.M.H., Kothe-Heinrich G., Omer S., Uotila P. 2001. Chenopodiaceae. In: Ali S.I., Qaiser M. (eds.). Flora of Pakistan, No. 204. Karachi: University of Karachi; St. Louis: Missouri Botanical Garden Press, 217 pp.

Gangopadhyay G., Das S., Mukherjee K.K. 2002. Speciation in Chenopodium in West Bengal, India. Genetic Resources and Crop Evolution, 49: 503-510. https://doi. org/10.1023/A:1020909128003

Grubov V.I. 1966. Plantae Asiae Centralis. Vol. 2: Chenopodiaceae. Leningrad: Nauka, 134 pp. [Грубов В.И. 1966. Растения Центральной Азии. Вып. 2: Chenopodiaceae. Ленинград: Наука, 134 pp.]

Grubov V.I. (ed.) 2000. Catalogue of the type specimens of Central Asian vascular plants in the herbarium of the V.L. Komarov Botanical Institute (LE). St. Petersburg: St. Petersburg University Press, 236 pp. [Каталогтиповых образиов сосудистьхх растений Центральной Азии, хранящихся в Гербарии Ботанического института имени В.Л. Комарова (LE). Ред. В.И. Грубов. СанктПетербург: Издательство Санкт-Петербургского университета, 236 с.]. 
Heyne B. 1814. Tracts, historical and statistical, on India: with journals of several tours through various parts of the peninsula: also, an account of Sumatra, in a series of letters. London: Printed for Robert Baldwin; and Black, Parry and Co., Booksellers for the Hon. East India Company, xii +462 pp.

Hiepko P. 1987. The collections of the Botanical Museum Berlin Dahlem (B) and their history. In: Scholtz H. (ed.). Botany in Berlin [special issue]. Englera, 7: 219-252.

Iamonico D. 2018. Nomenclatural and taxonomic notes on Acroglochin and its position in Chenopodiaceae s. str. Phytotaxa, 383(2): 197-205. https://doi.org/10.11646/ phytotaxa.383.2.6

Ikonnikov S.S. 1963. Identification manual of plants of the Pamir. Dushanbe: Academy of Sciences of the Tajik SSR, 282 pp. [Иконников С.С. 1963. Определитель растений Памира (Труды Памирской биологической станции Ботанического института АН Таджикской ССР, т. 20). Душанбе: Изд-во АН Таджикской ССР, 282 с.].

Ikonnikov S.S. 1979. Identification manual of higher plants of Badakhshan. Leningrad: Nauka, 400 pp. [Иконников С.С. 1963. Определитель высших растений Бадахшана. Ленинград: Наука, 400 с.].

Iljin M.M. 1936a. New species of the family Chenopodiaceae of the flora of the USSR. Acta Instituti Botanici Academiae Scientiarum URSS, Ser. 1: Flora et Systematica Plantae Vasculares, 2: 123-132. [Ильин М.M. 1936а. Новые виды сем. Chenopodiaceae флоры CССР. Tруды Ботанического института Академии наук СССР, сер. 1: Флора и систематика высших растений, 2: 123-132].

Iljin M.M. 1936b. Chenopodiaceae. In: Komarov V.L. (ed.). Flora URSS, vol. 6. Moscow; Leningrad: Editio Academiae Scientiarum URSS, pp. 2-354. [Ильин M.M. 1936b. Chenopodiaceae. В кн.: Флора СССР, т. 6. Ред. В.Л. Комаров. Москва; Ленинград: Изд-во АН СССР, c. 2-354].

Iljin M.M. 1952. Chenopodiaceae. In: Kotov M.I. (ed.). Flora URSR, vol. 4. Kyiv: Academy of Sciences of the Ukrainian SSR Publ., pp. 267-313, 650. [Ільїн М.M. 1952. Флора Украӥнської РСР, т. 4. Ред. М.І. Котов. Київ: Видавництво АН УРСР, с. 267-313, 650].

Iljin M.M., Aellen P. 1936. Chenopodium. In: Komarov V.L. (ed.). Flora URSS, vol. 6. Moscow; Leningrad: Editio Academiae Scientiarum URSS, pp. 41-73, 873. [Ильин М.М., Эллен П. 1936. Флора СССР, т. 6. Ред. В.Л. Комаров. Москва; Ленинград: Изд-во АН СССР, c. $41-73,873]$.

Kadereit G., Freitag H. 2011. Molecular phylogeny of Camphorosmeae (Camphorosmoideae, Chenopodiaceae): Implications for biogeography, evolution of $\mathrm{C}_{4}$ photosynthesis and taxonomy. Taxon, 60(1): 51-78. https://doi.org/10.1002/tax.601006

Kumar V., Subramaniam B. 1987. Chromosome atlas of flowering plants of the Indian Subcontinent, 2 vols (vol. 1: Dicotyledons). Calcutta [Kolkata]: Botanical Survey of India, xxvi $+1095 \mathrm{pp}$.
Kuntze O. 1892. Revisio generum plantarum..., vol. [pars] 2. Leipzig: A. Felix [etc.], pp. 377-1011. https://doi. org/10.5962/bhl.title.327

Lendemer J.C. 2020. Epitypes are forever: Best practices for an increasingly misused nomenclatural action. Taxon, 69(5): 849-850. https://doi.org/10.1002/tax.12289

Mandák B., Krak K., Vít P., Pavlíková Z., Lomonosova M.N., Habibi F., Lei W., Jellen E.N., Douda J. 2016. How genome size variation is linked with evolution within Chenopodium sensu lato. Perspectives in Plant Ecology, Evolution and Systematics, 23: 18-32. https://doi.org/10.1016/j. ppees.2016.09.004

Mandák B., Krak K., Vít P., Lomonosova M.N., Belyayev A., Habibi F., Wang L., Douda J., Štorchová H. 2018. Hybridization and polyploidization within the Chenopodium album aggregate analysed by means of cytological and molecular markers. Molecular Phylogenetics and Evolution, 129: 189-201. https://doi. org/10.1016/j.ympev.2018.08.016

Mazumdar J., Bandyopadhyay S., Bhattacharjee A. 2020. (013) Proposal to amend Article 9.20. Taxon, 69(3): 631. https://doi.org/10.1002/tax.12253

Mehra P.N., Malik C.P. 1963. Cytology of some Indian Chenopodiaceae. Caryologia, 16(1): 67-84. https://doi.or $\mathrm{g} / 10.1080 / 00087114.1963 .10796085$

Merrill E.D. 1943. Destruction of the Berlin Herbarium. Science, 98(2553): 490-491. https://doi.org/10.1126/ science. 98.2553 .490

Mosyakin S.L. 1996. Chenopodium. In: Tzvelev N.N. (ed.). Flora Europae Orientalis, vol. 9. St. Petersburg: Mir i Sem'ya-95, pp. 27-44. [Мосякин С.Л. 1996. Chenopodium. В кн.: Флора Восточной Eвропь, т. 9. Ред. Н.Н. Цвелев. Санкт-Петербург: Мир и семья-95, c. 27-44].

Mosyakin S.L. 2016. First record of Chenopodium ficifolium subsp. blomianum (Chenopodiaceae) in North America. Phytoneuron, 2016-33: 1-6. Available at: http:// www.phytoneuron.net/2016Phytoneuron/33PhytoNChenopodiumblomianum.pdf

Mosyakin S.L. 2017. Notes on taxonomy and nomenclature of Chenopodium acerifolium and C. betaceum (C. strictum auct.) (Chenopodiaceae). Phytotaxa, 324(2): 139-154. https://doi.org/10.11646/phytotaxa.324.2.3

Mosyakin S.L., Mandák B. 2018a. (2658) Proposal to reject the name Atriplex bengalensis (Chenopodium bengalense) (Chenopodiaceae / Amaranthaceae sensu APG). Taxon, 67(6): 1218-1219. https://doi.org/10.12705/676.27

Mosyakin S.L., Mandák B. 2018b. (2659) Proposal to conserve the name Chenopodium giganteum (Chenopodiaceae / Amaranthaceae sensu APG) with a conserved type. Taxon, 67(6): 1220-1221. https://doi.org/10.12705/676.28

Mosyakin S.L., Mandák B. (submitted, expected in 2021). Proposal to reject the name Chenopodium pallidum (Chenopodiaceae / Amaranthaceae sensu APG). Taxon, $70(1)$.

Mosyakin S.L., McNeill J. 2018. On the nomenclature of Chenopodium pallidum and Atriplex schugnanica (Chenopodiaceae / Amaranthaceae sensu APG) and the 
perils of epitypification. Phytotaxa, 376(3): 133-137. http://dx.doi.org/10.11646/phytotaxa.376.3.2

Mueller F. von. 1882. Systematic census of Australian plants, with chronologic, literary and geographic annotations. Part I. Vasculares. Melbourne: Printed for the Victorian Government by M'Carron, Bird \& Co., 152 pp. https://doi. org/10.5962/bhl.title.54034

Mukherjee K.K. 1986. A comparative study of two cytotypes of Chenopodium album in West Bengal, India. Canadian Journal of Botany, 64(4): 754-759. https://doi.org/10.1139/ b86-097

Murr J. 1923. Neue Übersicht über die Farn- und Blütenpflanzen von Vorarlberg und Liechtenstein, vol. 1. Feldkirch: Kommissionsverlag, Buchhandlung F. Unterberger, xxiv $+144 \mathrm{pp}$.

Novoselova M.S. 2000. Chenopodiaceae. In: Grubov V.I. (ed.). Catalogue of the type specimens of Central Asian vascular plants in the herbarium of the V.L. Komarov Botanical Institute ( $L E)$. St. Petersburg University Press, St. Petersburg, pp. 83-93. [Новоселова М.C. 2000. Chenopodiaceae. В кн.: Каталог типовых образиов сосудистых растений Центральной Азии, хранящихся в Гербарии Ботанического института имени В.Л. Комарова (LE). Ред. В.И. Грубов. Санкт-Петербург: Издательство Санкт-Петербургского университета, c. 83-93].

Pandeya C.S., Pandeya A. 2003. Further contribution to biosystematics of Chenopodium, reporting three new species from north Indian plains. Journal of the Bombay Natural History Society, 100(1): 87-92.

Pandeya C.S., Singhal G., Bhatnagar A.K. 1998. Biosystematic study of two new species of Chenopodium from the north Indian plains. Journal of the Bombay Natural History Society, 95(3): 477-487.

Partap T., Kapoor P. 1985a. The Himalayan grain chenopods. I. Distribution and ethnobotany. Agriculture, Ecosystems and Environment, 14: 185-199.

Partap T., Kapoor P. 1985b. The Himalayan grain chenopods. II. Comparative morphology. Agriculture, Ecosystems and Environment, 14: 201-220.

Partap T., Kapoor P. 1987. The Himalayan grain chenopods. III. An under-exploited food plant with promising potential. Agriculture, Ecosystems and Environment, 19: 71-79.

Partap T., Upadbya M.D. 1987. The Himalayan grain chenopods: floral variations and their role in seed formation. Agriculture, Ecosystems and Environment, 18: 205-210.

Pilger R. 1953. Bericht über den Botanischen Garten und das Botanische Museum Berlin-Dahlem vom 1. März 1943 bis 31. März 1947. Mitteilungen aus dem Botanischen Garten und Museum Berlin-Dahlem, 1(1): 1-21. Available at: https://www.jstor.org/stable/3995179

POWO. 2020-onward. Plants of the World Online. Facilitated by the Royal Botanic Gardens, Kew. Available at: http:// www.plantsoftheworldonline.org (Accessed 17 June 2020 and 20 August 2020).

Prakash R.O. 2016. Wallich and his contribution to the Indian natural history. Rheedea, 26(1): 13-20.
Pratov U. 1972. Chenopodiaceae. In: Vvedensky A.I. (series ed.), Bondarenko O.N., Nabiev M.M. (volume eds.). Identification manual of plants of Central Asia. Critical checklist of the flora [Alternative Latin title: Conspectus Florae Asiae Mediae], vol. 3. Tashkent [Toshkent]: Fan [Editio Academiae Scientiarum UzSSR], pp. 29-137. [Пратов У. 1972. Chenopodiaceae. В кн.: Определитель растений Средней Азии. Критический конспект флоры, т. 3. Ред. А.И. Введенский; ред. тома О.Н. Бондаренко, Набиев М.М. Ташкент: ФАН, с. 29-137].

Rana T.S., Narzary D., Ohri D. 2010. Genetic diversity and relationships among some wild and cultivated species of Chenopodium L. (Amaranthaceae) using RAPD and DAMD methods. Current Science, 98(6): 840-846.

Rilke S. 1999. Revision der Sektion Salsola s.l. der Gattung Salsola (Chenopodiaceae). Bibliotheca Botanica, 149: 1-190.

Roy R.D. 1986. The Great Trigonometrical Survey of India in a historical perspective. Indian Journal of History of Science, 21(1): 22-32.

Rubtsova O.L. 2004. Ukrainian Botanical Journal, 61(5): 102-108. [Рубцова О.Л. 2004. Володимир Геннадійович Хржановський. Наукова спадщина (до 90-річчя від дня народження). Украӥнський ботанічний журнал, 61(5): 102-108].

Scott A.J. 1978. A revision of Camphorosmioideae (Chenopodiaceae). Feddes Repertorium, 89(2-3): 101119. https://doi.org/10.1002/fedr.19780890202

Sidorenko G.T. 1968. Atriplex. In: Ovchinnikov P.N. (ed.). Flora of the Tajik SSR, vol. 3. Leningrad: Nauka, pp. 330-342. [Сидоренко Г.Т. 1968. Atriplex. В кн.: Флора Таджикской ССР, т. 3. Ред. П.Н. Овчинников. Ленинград: Наука, с. 330-342].

Singh B.K. 2015a. VRCHE-4: a bathua (Chenopodium album) germplasm for high yield and multi-cutting. Vegetable Newsletter. ICAR - Indian Institute of Vegetable Research, 2(1): 8-9.

Singh B.K. 2015b. VRCHE-2 (IC0619019): High yielding genotype of bathua. Vegetable Newsletter. ICAR - Indian Institute of Vegetable Research, 2(2): 3.

Singh B.K., Pragya, Chaurasia S.N.S., Singh B., Singh P.M. 2018. Kashi Bathua-2: A bathua variety for higher nutrient and yield. Vegetable Science, 45(2): 291-293.

Singhal G. 1994. Ecological studies on Chenopodium album complex: PhD Thesis in Botany. Dayalbagh, Agra, India: Dayalbagh Educational Institute (Department of Botany), viii + 95 pp. Available at: http://hdl.handle. net/10603/205080

Sleumer H. 1949. The Botanical Gardens and Museum at Berlin-Dahlem. Kew Bulletin, 4(2): 172-175. https://doi. org/10.2307/4113675

Stafleu F.A., Cowan S.R. 1988. Taxonomic literature. A selective guide to botanical publications and collections with dates, commentaries and types, $2^{\text {nd }}$ ed., vol. 7. W-Z. Utrecht/Antwerpen: Bohn, Scheltema \& Holkema; The Hague/Boston: Dr. W. Junk b.v., Publishers, lvi + 653 pp. 
Stewart R.R. 1982. Missionaries and clergymen as botanists in India and Pakistan. Taxon, 31(1): 57-64. https://doi. org/10.2307/1220590

Sukhorukov A.P. 2006. Zur Systematik und Chorologie der in Russland und benachbarten Staaten (in den Grenzen der ehemaligen UdSSR) vorkommenden Atriplex-Arten (Chenopodiaceae). Annalen des Naturhistorischen Museums in Wien. Series B, 108: 307-420.

Sukhorukov A.P. 2014. The carpology of the family Chenopodiaceae in relations to problems of phylogeny, systematics and diagnostics of its representatives. Tula: Grif i K, 400 pp. [Сухоруков А.П. 2014. Карпология семейства Chenopodiaceae в связи с проблемами филогении, систематики и диагностики его представителей. Тула: Гриф и К., 400 с.].

Sukhorukov A.P., Kushunina M. 2014. Taxonomic revision of Chenopodiaceae in Nepal. Phytotaxa, 191(1): 10-44. http://dx.doi.org/10.11646/phytotaxa.191.1.2

Sukhorukov A.P., Kushunina M. 2015. Corrigenda to "Taxonomic revision of Chenopodiaceae in Nepal" [Phytotaxa 191: 10-44. 2014]. Phytotaxa, 226(3): 288291. http://dx.doi.org/10.11646/phytotaxa.226.3.10

Sukhorukov A.P., Liu P.L., Kushunina M. 2019. Taxonomic revision of Chenopodiaceae in Himalaya and Tibet. PhytoKeys, 116(5-6): 1-141. https://doi.org/10.3897/ phytokeys.116.27301

Thiers B. 2008-onward. Index Herbariorum. A global directory of public herbaria and associated staff. New York Botanical Garden's Virtual Herbarium. Available at: http://sweetgum.nybg.org/science/ih (Accessed 04 May 2020 and 20 August 2020).

Turland N.J., Wiersema J.H., Barrie F.R., Greuter W., Hawksworth D.L., Herendeen P.S., Knapp S., Kusber W.-H., Li D.-Z., Marhold K., May T.W., McNeill J., Monro A.M., Prado J., Price M.J., Smith G.F. 2018. International Code of Nomenclature for algae, fungi, and plants (Shenzhen Code) adopted by the Nineteenth
International Botanical Congress, Shenzhen, China, July 2017 [Regnum Vegetabile, vol. 159]. Glashütten: Koeltz Botanical Books, xxxviii + 254 pp. https://doi. org/10.12705/Code.2018

Turland N.J., Wiersema J.H., McNeill J. 2020. (007-008) Proposals to make clearer the circumstances under which a holotype can exist. Taxon, 69(3): 626-627. https://doi. org/10.1002/tax.12248

Uotila P., Lomonosova M.N. 2016. Taxonomic circumscription and synonymy of Chenopodium karoi and C. acerifolium (Chenopodiaceae). Annales Botanici Fennici, 53: 223237. https://doi.org/10.5735/085.053.0411

Wallich N. 1832. A Numerical List of dried specimens of plants in the East India Company's Museum: collected under the superintendence of Dr. Wallich of the Company's botanic garden at Calcutta, nos. 6225-7683. Lithographed from a manuscript by N. Wallich and G. Bentham, London. https://doi.org/10.5962/bhl.title.1917

Watson M. 2013a-onward. The Wallich Catalogue Project. Available at: http://stories.rbge.info/archives/865 (Accessed 04 May 2020 and 20 August 2020).

Watson M. 2013b-onward. Wallich Catalogue: Herb., Hb. \& H. Available at: https://stories.rbge.org.uk/archives/2103 (Accessed 04 May 2020 and 20 August 2020).

Watson M.F., Noltie H.J. 2016. Career, collections, reports and publications of Dr Francis Buchanan (later Hamilton), 1762-1829: natural history studies in Nepal, Burma (Myanmar), Bangladesh and India. Part 1. Annals of Science, 73(4): 392-424. https://doi.org/10.1080/000337 90.2016 .1195446

Wilson P.G. 1984. Chenopodiaceae. In: George A.S. (ed.). Flora of Australia, vol. 4. Canberra: Australian Government Publishing Service, pp. 81-317.

Zhu G.L., Sanderson S.C. 2017. Genera and a new evolutionary system of World Chenopodiaceae. Beijing: Science Press, 361 pp.

Recommended for publication by N.M. Shyian 